\title{
FORGIVENESS IN MARRIAGE: FROM CURE TO HEALING
}

\author{
Rev. Prof. PhD. Bassam NASSIF \\ "St. John of Damascus" Institute of Theology, University of Balamand, Lebanon \\ https://doi.org/10.47433/tv.xcviin1-4.126
}

\begin{abstract}
The act of forgiveness is pivotal in the dynamics of family life. Today's unprecedented rise in divorce case numbers indicate that marital relationships are being shaken by the spirit of independence and individualism in the postmodern society. Resorting to psychotherapists to deal with these marital conflicts does not yield to a complete solution of the relational crisis or to healing the deep human wounds, thus restoring freedom. In this research, select psychological models of John Bowlby, Carl Jung, and John Gottman to deal with conflicts and forgiveness in family relationships are presented. To dialog with and examine these models, corresponding Christocentric approaches of St. Porphyrios of Kafsokalyvitis, St. Paisios the Athonite, and St. John Chrysostom are also presented. The latter pastoral approaches show how Christ gives not just a cure to human resentment and guilt, which is a matter supported by psychotherapy, but also bestows the mystery of forgiveness upon humankind, bringing about inner peace, reconciliation, joy, marital unity, and ultimately ontological healing. The paper explains how these Patristic approaches are actualized through the essential role and work of the spiritual guide in directing the husband and wife and helping them to live a healthy family life.
\end{abstract}

Keywords: Marriage, Family, Forgiveness, Psychoanalysis, Spirituality, Orthodox Church, Postmodernity, St. John Chrysostom, St. Porphyrios Kafsokalyvitis, St. Paisios the Athonite, Elder Aimilianos of Simonopetra, Ann Ulanov, Carl Jung, John Bowlby, John Gottman.

\section{Introduction}

Family life involves communion and fellowship, but it is also a training field for facing the world and its relational complexities, and especially for negotiating differences and conflicts. The nuclear family relationships include dealing with collective memories, family secrets, various degrees of emotions, and shared possessions or homes. They also involve complex interpersonal dynamics that require great caution in handling them. These dynamics are not just on the level of husband and wife, but also between parents 
and children, as well as among the children themselves. Forgiveness opens the way for marital communion to strive. ${ }^{1}$

Real incompatibilities and "mis-loved" partner are often found in marriages. However, today's unprecedented rise in divorce case numbers indicate that these essential bonds of human life are being shaken, and the spirit of independence and individualism in the postmodern society is increasingly challenging the life of communion in marriage. Divorce has become a personal business done by mutual consent, due to some "irreconcilable differences," as they say. Resorting to psychotherapists to deal with these marital conflicts does not yield to a complete solution of the relational crisis. The reason for this is that psychology deals with the inner workings of the human psyche. However, life in Christ, or the Christian theanthropic approach, involves all human dimensions: psychological, physical, social, and spiritual. How can this life in Christ actualize the power of forgiveness among family members, leading them to a reconciled and healthy family life?

In this article, we will present anthropocentric approaches or psychological models to deal with conflicting differences in family and curing them. Then, we present the corresponding Christocentric, Patristic approaches, which bring about healing of human relationships. The latter shows how Christ gives not just a cure to human resentment, but also bestows the mystery of forgiveness and brings reconciliation, healing, and the joy of life.

\section{Psychological Views on Resolving a Conflict}

One of the main structural elements of postmodernity is the desire to connect effectively and communicate vividly with the other. Communication is a desire for communion. However, the weakened state of connectedness and marital relationships in current society lies in a "collision between love, family, and personal freedom" 2 . This collision creates a conflict resulting from the current shift

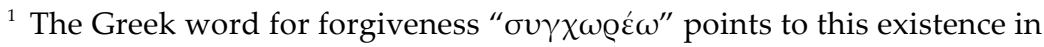
communion. It is a composite of two words: the preposition " $\sigma u ́ v$ " which indicates a togetherness, and the verb " $\chi \omega \varrho \varepsilon ́ \omega$ " which means to allow the others, sinful as they are, to exist together with me and fit in.

${ }^{2}$ Ulrich Beck and Elizabeth Beck-Gernsheim. The Normal Chaos of Love, translated by M. Ritter and J. Wiebel, Polity Press, Cambridge 1995, pp. 1-2. 
from a community-based society to an individualistic one. This shift opens the door for each spouse's financial independence and freedom of choice, generating many conflicts and leading to higher rates of divorce. The two competing forces in the postmodern age are individual liberty and egalitarian attitudes. Since forgiveness thrives in healthy family relationships, the resilience of connectedness and relational embeddedness in personal relationships is clearly impacted. Forgiveness seems to be as an unreachable act, to be dismissed in its essence. This leads to the gloomy conclusion that marriage and family life in postmodern society is a communion of unforgivers and a fellowship of incompatible individuals.

There are various psychological approaches to deal with these marital incompatibilities that wound spouses and break marriages and remove the "mental" state of hatred and unforgiveness. Three of these notable approaches are about the attachment theory of John Bowlby, the dynamics of one's psyche according to the Jungian approach, and the styles of communication approach by John Gottman.

\section{Bowlby and the Attachment Theory}

Bowlby theorizes that one of the main causes of the relational failings lie in the maturity of the early attachment behavior between mother (the primary caregiver) and infant. Since humans are created to connect and form emotional attachment bonds, the disturbance (through unavailability, anxiety, indifference, etc.) of this mother-child attachment in the first two years critical in the baby's growth creates a disposition affecting future attachment bonds in a marital relationship. Thus, the quality of initial maternal care and love has a lasting impact on the success of future relationships. ${ }^{3}$ The initial great care is crucial for relational stability in marriage, since it matures in a spouse the propensity to reconcile and forgive. This theory has created much anxiety for mothers who, living in a consumerist, busy world, are trying to give more time to the upbringing of their children. As a result, some have reviewed their work commitments after delivering a child.

${ }^{3}$ John Bowlby, Mary Ainsworth, Mary Boston, and Dina Rosenbluth, "The Effects of Mother-Child Separation: A Follow-up Study," British Journal of Medical Psychology, vol. 29, no 3-4, 1956, pp. 211-249. 


\section{Jung and the Coniunctio}

Psychoanalyst and theologian Ann Ulanov believes that the relationship between the married couple, or what she calls the "hierosgamos", is a sort of "coniunctio" archetype, or union of opposites, and the workings of the person's psyche and emotional memories, causing radical changes in the most habitual behavior. ${ }^{4}$ Ulanov makes an important contribution based on the Jungian psychotherapeutic approach. She researched how, through the desire to love in total freedom, the areas of conflict and tension between the husband and wife in marriage are dealt with, and how these interactions shape both partners and reform their personalities, transforming their egoistic desires.

This experience leads both husband and wife to know their true self (instead of remaining in their narcissistic false self), and to go out of their self-love, or confluent love, knowing their limits and reaching a stage of forgiveness and love. However, the overemphasis on the psychological, or mental, dimension of relationships leads to either missing the spiritual dimension of these emotional and rational dynamics in relationships, or confusing spirituality with psychology. Thus, the need is for a comprehensive understanding of human existence and a holistic view of the "human being in relation", comprising all distinct, but interrelated, human dimensions.

\section{Gottman and the Four Horsemen of the Apocalypse}

Another psychologist and marriage counsellor, John Gottman, has done widely known extensive research on marital conflicts and their cure. Gottman saw that one main conflict among spouses arises from miscommunication. It is generated by a lack of intimate connectedness between spouses. Instead of expressing in a respectful, honest, careful, and responsible way their fears, needs, and desire, Gottman concluded that spouses use four negative styles of communication, which lead to the breaking of their marriage: "criticism, contempt, defensiveness and stonewalling"

${ }^{4}$ Ann Belford Ulanov, Spiritual Aspects of Clinical Work, Daimon Verlag, Einsiedeln, 2004, p. 132.

${ }^{5}$ John Gottman and Nan Silver, The Seven Principles for Making Marriages Work, Three Rivers Press, New York, 1999, pp. 25-46. 
Gottman labeled these the "Four Horsemen of the Apocalypse", an image he used from chapter six of the Book of Revelation that corresponds to the advent of four plagues: conquest, war, famine, and death, destroying the earth and all those in it.

Clearly, overcoming deep, ingrained, and complex memories, hurts, and suffering generates a personal existential struggle. Gottman presents important issues to be dealt with in relationships, but what is the root cause of these issues? What is behind these negative communication styles?

Are these aforementioned approaches or psychological models complete in terms of terms of their functional capacity to formulate forgiveness within the family? What is the Orthodox Church's approach to forgiveness in marriage, especially in relation to these approaches proposed in psychology?

\section{Orthodox Patristic Views on Forgiveness}

\section{St. Porphyrios and Divine Attachment}

St. Porphyrios gives a great emphasis on the importance of the intimate bond between both mother and father on the one hand, and the child on the other. He considers the attachment to begin from the moment of the child's conception, and not just after the infant's delivery. ${ }^{6}$ From his work in spiritual direction, he relates many examples of troubled families and divorces that resulted from the early wounds carried by the parents from their upbringing. He explains that, "A psychological state is created in a child as a result of its parents that accompanies it throughout its life. Its later behavior and its relationships are directly connected with the experiences that it carries with it from its childhood years" ${ }^{7}$. This contemporary saint emphasizes not just the care of parents for their children, but also the husband and wife's cooperative, harmonious, and stable relationship as the unique source of the child's future healthy attachment bonds and spiritual development. In addition, all emotional attachment with the mother ought to be accompanied by the mother's attachment to God. This creates in

${ }^{6}$ St. Porphyrios Kafsokalyvitis, Wounded by Love: The Life and the Wisdom of Saint Porphyrios, Limni, Denise Harvey, 2005, p. 195.

${ }^{7}$ Ibidem, p. 197. 
the child a deeper and much more secure attachment that will contribute to establishing healthy relationships in the future. ${ }^{8}$

The lives of the mothers of several saint-theologians mentioned in this study witness to this truth: Basil the Great's mother: St. Emelia; Gregory the Theologian's mother: St. Nonna; and John Chrysostom's mother: St. Anthousa. This Divine attachment explains the essential value of another important dimension of Christian life: early infant baptism, which is the incorporation of the infant by the parents into the liturgical life of the Church.

A peaceful and harmonious relationship between husband and wife leads to rearing well-balanced children. As St. Porphyrios confirms from his contemporary and vast experience in spiritual direction, "What saves and makes for good children is the [holiness] life of the parents in the home... Love, harmony and understanding between parents are what are required for the children" ${ }^{\prime \prime}$. In other words, parents, who personally experience the love of God and live this freedom in Christ in humility of heart are free from the captivity of emotional attachment. They are given to teach their children the ways to overcome mutual injustices and disappointments, through their efforts to break the cycle of revenge and overcome emotions of resentment and anger. Their living example of love each and reconciliation trains their children in how to actualize forgiveness.

\section{St. Paisios and Divine Harmony}

The family is comprised of various personalities that carry different levels of interpersonal skills. It is a dynamic field for human character formation. A family living within the Church has the potential to mold "in Christ" the persons who are family members, and prepare them for citizenship in the Kingdom. Living in the secular world, however, the family is pulled into the dynamics of secular society and its individualistic and materialistic lifestyles which emphasize the protection of individual rights and private justice. Differences between two diverse personalities may result in conflict and divorce. For St. Paisios, love and forgiveness begin with repentance and confession, since he understands sin to rise

\footnotetext{
${ }^{8}$ Ibidem, pp. 199-202.

${ }^{9}$ Ibidem, p. 196.
} 
from unresolved conflicts. This inner repentance opens the way for wounds of injustice to be transformed by God's help into spiritual blessings. ${ }^{10}$

When one spouse discovers his or her personal weakness, then one begins to beg in humility for God's mercy, and to see the sins of the others with an eye of compassion and mercy. So, living under the fear of God is what makes marriage successful. St. Paisius defines this kind of fear as "respect for God, devotion and spiritual reserve... it is something sacred" ${ }^{11}$. He notes that love and respect are not two different things; "they are one and the same" ${ }^{\prime 12}$. With God's help, both spouses need to pay constant attention to their interior life that they might overcome and transfigure their differences. He advises the man who is seeking to get married to abide by the following plan:

[The couple] should cultivate, as far as possible, the virtue of love, so the two of them will always remain in such a way that the Third our Sweetest Lord Jesus Christ - will also remain with them... Some men tell me: 'I don't agree with my wife; we are complete opposites! How does God allow for such strange matches? Couldn't He provide so that couples would be compatible and live spiritually?' But I tell them, 'Don't you understand that in this very difference of character lies hidden the harmony of God? It is the different characters which create harmony. ${ }^{13}$

The words of St. Paisios affirm that forgiveness is not reducible to chemical reactions in the brain. It is rather the power of God that brings to the human being inner change, yielding reconciliation with the other and with God. The work of the human being imitating the life in Christ, synergically with Divine grace is the only power capable of redeeming personalities and transforming eros from a narcissistic, egocentric self-love to a sacrificial, selfless love. This transformation occurs in the "hidden man of the heart" (1 Peter 3:4). Only by acquiring this love humans, as Deacon Stephanos,

${ }^{10}$ Elder Paisios the Athonite, Paisios the Athonite. Spiritual Counsels III: Spiritual Struggle, Sacred Hesychastirion of St. John the Evangelist, Souroti, Greece, 2010, p. 77.

${ }^{11}$ Elder Paisios the Athonite, Paisios the Athonite. Spiritual Counsels IV: Family Life, Sacred Hesychastirion of St. John the Evangelist, Souroti, Greece, 2014, p. 45.

${ }^{12}$ Ibidem, p. 44.

${ }^{13}$ Ibidem, pp. 40-41. 
the First Martyr, can say repeat the words of Christ: "Father, forgive them; for they do not know what they are doing" (Luke 23:34). This is testified in the narratives of the Synaxarion. ${ }^{14}$

\section{St. John Chrysostom and Divine Communication}

As a first step towards effective communication, St. John Chrysostom instructs the faithful to be first tolerant with the neighbor, and by extension with the spouse, in imitation to the tolerance of God's love towards humans, since "Wherever there is love, all things are to be borne." ${ }^{\prime 15}$ This gift of being tolerant of one another is given in their relationship to Christ, in His imitation (Mathew 6:12, Luke 6:36, John 8:31-32; Galatians 5:1,13), and in partaking of the Eucharist: "First be reconciled to your sister or brother, and then come and offer your gift" (Matthew 5:24).

For both the man and his wife, learning how to connect, have peaceful dialogue, uphold empathic listening, negotiate, and resolve conflict are important skills that add harmony to their lives, strength to their marriage. These skills also affect the education and formation of their children. In fact, effective listening involves the act of turning toward the other as a sign of care. Thus, sharing and listening denotes establishing an effective communication of love.

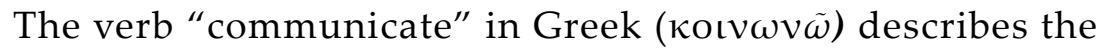
communion of the spouses, which includes mutual exchange, cooperation, and collaboration on issues pertaining to life. For Chrysostom, Adam's socialization requires him to have connectedness through communication and exchange with someone equal to him: "The

\footnotetext{
${ }^{14}$ David and Mary Ford gathered over one hundred and eighty accounts of ancient and contemporary married saints, in the book titled Marriage as a Path to Holiness. Lives of Married Saints. One example is a saint from the tenth century, Thomais of the Greek island of Lesbos, fell in love and married a man named Stephanos. Thomais was deceived about Stephanos. Stephanos turned out to be an angry and resentful man. Taking refuge in prayer and spiritual guidance, she endured domestic trials for thirteen years with much forbearance and a forgiving heart, until her death at the age of thirty-eight. By God's grace, her suffering and death were turned to victory. Her relics have been a source of many miracles, including the healing of her husband's temper.

${ }^{15}$ St. John Chrysostom, On Ephesians, Homily 9, Nicene and Post-Nicene Fathers, Series 1, vol. 13, edited by Philip Schaff and Henry Wace, Eerdmans, Grand Rapids, MI, 1999, p. 182; Patrologia Graeca, vol. 62, col. 72.
} 
human being that had been formed stood in need of someone to talk to [ $\pi$ @ò $\delta \iota \alpha \lambda \dot{\varepsilon} \gamma O \mu \alpha \iota$ ] and able to offer him much comfort by a sharing of her being"16.

Chrysostom emphasizes two ways of communication as connecting or even bonding elements between spouses: verbal and nonverbal. He gives the example of Eve who miscommunicated with Adam, since when she heeded to another voice, she fell. She ought to heed to the voice of the one who is equal in honor to her, who share the same nature, and for whom she was created. ${ }^{17}$ Therefore, using effective communication skills strengthens connectedness, brings about comfort and consolation to marriage, opens the way for unity and reconciliation, and allows the children to have a healthy environment to grow as human beings, form their character, and develop their personality. All this is done in humility needed to win over the other, as the Apostle commands it to be done "with all lowliness and gentleness, with longsuffering, bearing with one another in love" (NKJV, Eph. 4:2). The "four horsemen" mentioned by Gottman have their hidden root in a prideful heart. By knowing themselves and the level of self-love and pride that they struggle with, and in lamenting their pitiful fallen state, the married couple are able to look at each other with a merciful eye and forgive the trespasses of the other.

\section{Marriage is a Journey of Forgivers}

All these Patristic contributions consider that in Christian marriage, both the man and his wife, each with his or her distinct personality, are yoked together ( $\sigma 0 \zeta v \gamma i \alpha)$ forever. Realistically, this yoking is "a journeying together, a shared portion of pain, and, of course, a joy"18. It is also "a journey of love"19, during which the man and his wife grow together, intimately, permanently, and profoundly.

${ }^{16}$ St. John Chrysostom, On Genesis, Homily 15, Homilies in Genesis. Fathers of the Church, vol. 74, translated by Robert C. Hill, Catholic University of America Press, Washington, 2010, p. 200; Patrologia Graeca, vol. 53, col. 124.

${ }^{17}$ St. John Chrysostom, On Genesis, Homily 17, Homilies in Genesis. Fathers of the Church, vol. 74, pp. 240-241; Patrologia Graeca, vol. 53, col. 147.

${ }^{18}$ Archimandrite Aimilianos of Simonopetra, The Church at Prayer: The Mystical Liturgy of the Heart, Indiktos, Athens, Greece, 2015, p. 118.

${ }^{19}$ Ibidem, p. 120. 
Moreover, it is a journey of discovery, in which both the man and his wife discover their weaknesses, their frailty, and their inner brokenness. It is indeed a journey of two forgivers, who fall and get up again in exchanging forgiveness.

The essence of this journey of forgivers is the forgivers' foreknowledge that Christ took the initiative to show His love to them and died for them sinners (Rom. 8:7-9). Knowing that all have sinned and fell in enmity, He was crucified and risen, trampling death by death, conquering sin, granting justification by His blood, and reconciling humankind with God. He made each created being worthy of His forgiveness, righteousness, and reconciliation. ${ }^{20}$ Not even now, but also in the last judgement, He granted to those who abide "in Christ" (Rom. 8:1), "or more accurately [who abide] in the new state of righteousness and reconciliation, to be able to hope for the salvation in last judgment" ${ }^{21}$. Having the "mind of Christ" (1 Cor, 2:16). Christians, especially spouses and all family members, ought to imitate the Heavenly Father in being merciful (Luke 6:36), and to "learn from the example of Christ that through forbearance, mercifulness, and forgiveness, peace can be achieved on earth" ${ }^{22}$. Thus, the words of Lord's prayer, "Forgive us our trespasses, as we forgive them that trespass against us" (Matthew 6:12), becomes a daily bread broken on the table of sacrifice, feeding this marital journey.

The role of the Holy Eucharist is essential in the journey of forgivers. Chrysostom reminds that, in approaching the holy chalice, the spouses are warned that they ought to be united by forgiving each other in the name of Christ's love, before being united to Christ in the Eucharist. ${ }^{23}$ The more mature of the two needs to take the first step and open the door for forgiveness. The focus ought to be not on who errs, or why one does something, but on resolving the conflict with care and mercy. However, both spouses in our day and age are not able to achieve this journey without an external help. Unfortunately, the postmodern, individualistic trend is that

${ }^{20}$ Archimandrite Jack Khalil, "Peace, Mercy and Justice. Reconciling the World and Judging the World by God", Just Peace. Orthodox Perspectives, edited by Semegnish Asfaw, Alexios Chehadeh, and Marian Simion, WCC Publications, Geneva, 2012, p. 227-229.

${ }^{21}$ Ibidem, p. 229.

${ }^{22}$ Ibidem.

${ }^{23}$ St. John Chrysostom, “On Judas' Betrayal”, Patrologia Graeca, vol. 49, col. 382. 
of self-sufficiency, Google counselling, and do-it-yourself spirituality. The Church invites the couple to take the parish priest as a guide on this marital journey leading them to the Kingdom.

\section{Necessary Guide in this Journey}

Having a disposition of seeking and granting forgiveness enables the couple's relationship to mature. The failure in marital life is connected to a rejection of repentance by both spouses, through un-forgiveness and blaming each other for the wound, retaliating in resentment which yields to more suffering. This suffering cannot be overcome without God's help. Since marriage is ordained by God and the priest is the servant of God and God's people, the priest has a direct pastoral responsibility to care for the couple. The leader of the early Christians in Antioch, St. Ignatius of Antioch, asks the couple to take the blessings of the bishop, as follows: "When men and women marry, the union should be made with the consent of the bishop, so that the marriage may be according to the Lord, and not merely out of lust. Let all be done to the glory of God"24. These words clearly indicate that in the Early Church, bishops and priests had the role of caring pastorally for spouses. It is part of the Church's role as "a hospital that restores human wounds and helps people live a healthy life, emotionally, spiritually, and even physically" ${ }^{\prime 25}$. Facing bitterness, misery, and hate resulting from growing marital conflicts, the Church ought to open wider the door of mercy and forgiveness to Her faithful. She embraces the devastated married spouses and bring them back to Christ. Broken souls come to Church weary and heavily burdened. They seek rest and peace in Christ (Matthew 11:28).

For this, the Church needs prayerful priests, possessing the gift of discerning spirits, and well equipped with tools to integrate the moral teachings of the Church with pastoral care. Even though

${ }^{24}$ Ignatius of Antioch, The Letters, translated by Alistair Stewart, St. Vladimir's Seminary Press, Crestwood, NY, 2013, p. 126.

${ }^{25}$ Peli Galiti, "The Healing Art of Forgiveness", Caregivers as Confessors and Healers. Proceedings from the Annual National Conference of the Orthodox Christian Association of Medicine, Psychology and Religion, Hellenic College Holy Cross Greek Orthodox School of Theology, Brookline, MA, Nov. 5-7, edited by Stephen Muse, James Burg, and Halina Woroncow, Eight Day Institute, Wichita, KS, 2016, p. 149. 
the marital relationship has its own privacy, its spiritual growth is not a private matter between only the couple themselves. It needs support from God's grace and God's servants, the worshipping community, or the Body of Christ.

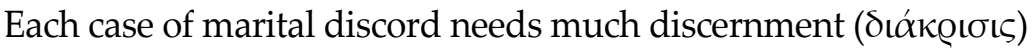
and prayers on behalf of, not just the couple, but also the parish community and the parish priest. Family dynamics pose many risks for the priest inexperienced in addressing marital crises. There is always a missing piece in the stories of conflicts, a certain hidden manipulation, and an inner passion that is hard to discover. However, the priest's care is not external to family life, which is an ecclesial entity with a clear spiritual dimension. The Church, as a caring Mother, has, through the priest, an active, personal role before, during, and after the crowning ceremony. She ought to provide support and accompaniment to the couple. The spiritual father does not act as a problem solver or take up the role of a psychologist attempting to relieve guilt, anxiety, depression, and distress. He does not favor forgiveness in the name of extenuation or condescension, but as a reconciliation in Christ's love.

In exercising the sacrament of reconciliation, the priest views the human being as a creation "in the image and on likeness of God". Thus, he acts as a physician of souls, embraces the spouses, and helps them rebuilt mutual trust and recommunicate. He guides them overcome their mutual hurt by seeing God's love and forgiveness. He shows them that they each are in the image of God, no matter how different from each other they may be. He leads them to know themselves and their sinful passions and return to God in humility and freedom. The essential role of the priest, urgently needed today, is to offer hope and courage in critical, seemingly unresolvable circumstances. Actually, "there is a great need of Holy people who can console and cure broken hearts and societies by their spiritual presence and the power of divine peace abiding in them" ${ }^{26}$.

Also, the priest in his academic and pastoral formation ought to have the ability to discern heuristically between the symptoms of the behavioral, emotional, and cognitive problems he encounters

\footnotetext{
${ }^{26}$ Fr. Porphyrios Georgi, "Peace and Peacemakers in Patristic Thought", Annals of St. John of Damascus Institute of Theology, vol. 11, 2016, p. 23.
} 
and the spiritual issues to be treated. This discernment is crucial for the good spiritual guidance and proper referral. Oftentimes, the suffering person is not able or even ready to listen to proper spiritual guidance because medical and psychological health issues need to first be addressed by mental health practitioners. The priest must not ignore the human's psychosomatic unity. There are both spiritual and natural (which includes psychological) issues that need to be cured, and both are intimately related.

\section{Conclusion}

In this Christocentric approach, forgiveness is a Divine virtue which renews inner thoughts, liberating the human heart from self-destructive resentment, revenge, and guilt. Living in communion with each other and God, both husband and wife go through a long-term struggle to reach a steady phase of constructive communication and mutual understanding of each other's strengths and limitations. Thus, forgiveness is built through one's ascetic struggle, guided by one's free will to be purged from the enslaving passions of hatred and receive inner freedom. Forgiveness does not erase the past, but the consequences of sinful enmity. It releases the potential for spiritual growth, a growth in Christ towards the Kingdom and the fulfillment of God's likeness. Thus, the Christocentric approach does not just psychologically cure human resentment, but also bestows upon fallen human beings the mystery of forgiveness, bringing about inner peace, holistic reconciliation, and ultimately ontological healing. In this sense, forgiveness in marriage is an eschatological journey of salvation reaching the fullness of communion between God and humankind.

In the end, forgiveness is a Divine gift of life to the human being imitating Christ and obeying His commandments, transforming every aspect of human life, including the human deepest self. This gift is bestowed by God through the channel of his mysteries served by his ministers and spiritual elders. In the journey of marriage, this gift reveals marriage as a mystery of love, and as a process of realizing marital unity, where the husband feels that his wife is part of himself, and vice versa. In the joy of this unity in love, the husband and wife offer their selves back to Christ as an act of thanksgiving, glorifying God for his eternal mercy. 